\title{
Chicken Production and Marketing System under Farmer's Management Conditions in Arsi and Bale Zones, Oromia Region, Ethiopia
}

\author{
MulualemAmbaw*, Mezgebworkye, Fekadu Seboka \\ Ethiopian Institute of Agricultural Research, Kulumsa Agricultural Research Center,P.O.Box \\ 489, Assela, Oromia,Ethiopia
}

*Corresponding Author: MulualemAmbaw, Ethiopian Institute of Agricultural Research, Kulumsa Agricultural Research Center, P.O.Box 489, Assela, Oromia, Ethiopia

\begin{abstract}
The study was conducted to characterize the indigenous chicken production and marketing system in selected districts in Arsi and Bale Zones of Oromia region. Structured questionnaire were used for data collection. Multi-stage stratified sampling method was used to stratify the study areas in to different agro ecological zones. The mean flock sizeperhousehold of the study area was 13.5poultry. Both cross and local chicken were managed traditionally in the study areas. Diseases and predators were the major causes of illness and deaths of poultry. About $64.2 \%$ of poultry death was observed during the rainy season. There was no systematic marketing operation of poultry and poultry products in the study areas. The major constraints of poultry production in the study areas were disease, market and feed shortage ranked as first second and third constraints regardless of agro ecologies. Attention should be given for the disease prevention and control by availing veterinary service and quality feed to improve production and productivity. In addition awareness creation and extension package to producer farmers about the proper management of poultry is Paramount important to utilize and conserve the ample indigenous poultry resource.
\end{abstract}

Keywords: Indigenous chicken production, agro ecology, marketing, production constraints

\section{INTRODUCTION}

Poultry production is a common practice in Ethiopia. According to central statistics agency (CSA, 2017) report; the totalpoultry population at country level is estimated to be about 56.53million.Most of thepoultry are chicks (41.35 percent), followed by laying hens (32.18 percent). Pullets are estimated to be about 5.85 million in the country. Cocks and cockerels are alsoestimated separately, and are 5.32 million and about 3.11 million, respectively. Theothers are non-laying hens that make up about 2.53 percent (1.51 million) of the totalpoultry population in the country. With regard to breed, 94.31 percent, 3.21 percentand 2.49 percent of the total poultry were reported to be indigenous, hybrid and exotic, respectively.

The most dominant chicken types reared in Ethiopia are local ecotypes, which show a large variation in body position, plumage color, comb type and productivity (Halima, 2007).Likewise, different names have been given to these chicken production sometimes used interchangeably, These includes: village, family, free range, scavenging, rural or traditional and smallholder chicken production (Cumming, R.B.1992; Tadelle and Ogle, 2001; Alemu, Y. 2003; Gausi, et al., 2004). Chicken production systems of tropical regions are mainly based on the scavenging indigenous chickens found in virtually all villages and households in rural area. Approximately $80 \%$ of the chicken populations in Africa are reared in these systems. With the exception of urban areas in northern and southern Africa, most poultry production in Africa is under taken through an extensive system at village or family level based on the scavenging domestic fowl (Gallus domestics) (Dwinger et al., 2003).

Chicken production system in Ethiopia is an indigenous and integral part of the farming system that ranges from nil input traditional free ranges to modern production system using relatively advanced technology. However, the traditional system is predominantly prevailing in the country and it is characterized by small flock, minimal in puts, periodic devastation with short lifecycle, quick turn over and unorganized marketing system. (Tadelle and Ogle, 2001; Alemu and Tadelle, 1997; Aberra, 
2000; Solomon, 2004).The indigenous chickens predominately prevailing in this system are low in productivity due to various reasons. Despite their low productivity, the indigenous chickens are known to possess desirable characters such as thermo tolerant, resistant to some disease, good egg and meat flavor, hard eggshells high fertility and hatchability as well as high dressing percentage (Aberra, 2000). However, In spite of the above important desirable characters, the indigenous chickens have been neglected in areas of scientific research on its characterization, performance potential, and development efforts.

Generally, in order for decision-makers to address the chicken production and marketing related challenges and improve the livelihoods and food security of rural households, it is essential to conduct a research that could generate appropriate chicken technologies, which is socially acceptable, environmentally sound and economically feasible. Although there are studies conducted on characterization of poultry production system in some places of the country, the studies made so far were not comprehensive because some works did not include the marketing component and/or did not correlate production and productivity with marketing situation and some of them was site specific. In addition, many government and non-government projects have been dealing with exotic chickens without due consideration given to their compatibility to the socio-economic circumstances, the ownership pattern, control and access of resources, distribution of benefits and marketing.

Therefore, comprehensive studies that run from production to marketing are worth understanding to provide full image of the overall production systems.So characterization of the prevailing production and marketing system is thus an obvious prime prerequisite to bring this into an effect. Thus, this study was initiated to characterize the smallholder chicken production and marketing systems in different agro ecologies of Arsi and Bale Zones as base line information generation for further research plane.

\section{RESEARCH METHODS}

\subsection{Description of the Study Area}

This study was conducted in selected districts of Arsi and Bale Zones Oromia Region. Arsi and Bale Zones are located at the South-Eastern part of Oromia Regional State. Arsi zone is $175 \mathrm{kms}$ far from the capital city Addis Ababa and one of the 22 zones of the Oromia National Regional State. It is located in the southeastern part of the country. It is also situated between $6^{\circ} 45^{\prime} \mathrm{N}$ to $8^{\circ} 58^{\prime} \mathrm{N}$ latitude and $38^{\circ} 32^{\prime} \mathrm{E}$ to $40^{\circ} 50^{\prime} \mathrm{E}$ longitude (EIDP.2002). It is characterized by mixed farming system. The mean annual temperature of the Zone ranges between $20^{\circ} \mathrm{C}-25^{\circ} \mathrm{C}$ in the low land and $10^{\circ} \mathrm{C}-15^{\circ} \mathrm{C}$ in the central high land (OCSA, 2012). It is also known for its surplus production and knows as wheatbelt of Ethiopia (Gebremariam, 1992). Bale zone is $389 \mathrm{~km}$ far from Addis Ababa and located at $7^{\circ}$, $00^{\prime} \mathrm{N}$ and $39^{\circ} 45^{\prime} \mathrm{E}$ and $7^{\circ}, 30^{\prime} \mathrm{N}$ and $39^{\circ}, 30^{\prime} \mathrm{E}$ of latitude and longitude, respectively. The zone rages from lowland to high lands which represent different agro-ecologies of Bale with altitude range of 500 to $4377 \mathrm{~m}$ above sea level. The annual minimum and maximum temperature of the area extends from 2 to $20^{\circ} \mathrm{C}$ for high land and 26 to $40^{\circ} \mathrm{C}$ for lowlands (Williams, 2002). In the area, there are two rainy seasons, the first and the main season extends from August to December with rain fall of 270 to 560 $\mathrm{mm}$ and the second and the short rainy season goes from April to July with rain fall of 250 to 560 $\mathrm{mm}$. The dry season covers from December to March (SARC, 2001)

\subsection{Sampling and Data Collection}

Stratified random sampling techniques were used to stratify the agro-ecological zone (high, mid and lowland). The numbers of kebeles to be surveyed were randomly selected from each stratum proportional to the size of the Wereda by consulting agricultural experts. Thus, one district in each Zones in each agro ecologies, a total of 6 districts from the two Zones were selected and 2kebeles from each districts with a total of 12 kebeles in each agro ecologies were randomly selected. From each randomly selected kebeles, about 8 households that possess five or more chickens were purposively selected after asking consent for participation to the survey for interview. Thus, 101 producer farmers were including in this study for interview during questionnaire survey. For marketing survey a purposive sampling technique were used to select market actors like sellers, buyers and middle men and women from each selected market places.

Primary data were collected by using structured questionnaire .A structured questionnaire that has a type of mixed questions with open ended and closed types were prepared. The questionnaire was 
pretested and adjusted before full administration. The focus areas of the questionnaire were perspectives of the chicken production system including intra household dynamics (division of labor, access to and control over of resources and decision making on resources), the functions and importance of chickens in the socio-economic live of the community such as cultural roles, traditional rites in the respective study areas. Information on indigenous and exotic breeds of chicken including; flock characteristics and ownership, the perspectives of functional traits and flock performance, use pattern, major constraints and all aspects of chicken managements were collected.

\subsection{Statistical Analysis}

SPSS software package 20 was used .Descriptive and inferential statistics were used to analyze quantitative and qualitative data sets. ANOVA model statement used to investigate the effects of agro ecologies difference on household characteristics (family size and chicken flock size per household) and various performance related parameters of chickens(age at first egg, number of clutches per year, clutch length, eggs/hen/year and inter clutch

\section{RESULT AND DISCUSSION}

\subsection{Socio-Demographics Characteristics of the Households in the Study Areas}

Socio demographics characteristics of the households in the study areas are described in (table 1) below. About 93 of the interviewed producer farmers were male, while the remaining 8 of them were females. The overall mean family size of sample households was 6.62 . This value was higher than the national average 5.2 persons (CSA, 2003). The average family size in different agro ecologies were $6.64,6.85$ and 6.38 in highland, midland and lowland respectively, which is nearly similar with the report of Mekonnen, (2007). The overall mean of age of respondents was 36.24 years, average age of respondents in highland, midland and lowland were 37.57, 35.91 and 33.95, respectively.

Table1. Socio demographic characteristics of the household

\begin{tabular}{|l|l|l|l|}
\hline \multirow{2}{*}{ Agro ecology } & \multirow{2}{*}{$\mathbf{N}$} & Family size & Age of respondents \\
\cline { 3 - 4 } Highland & 46 & Mean \pm SE & Mean \pm SE \\
\hline Midland & 33 & $6.64 \pm 0.55$ & $37.57 \pm 1.92$ \\
\hline Lowland & 22 & $6.85 \pm 0.28$ & $35.91 \pm 1.93$ \\
\hline Overall mean & 101 & $6.38 \pm 0.71$ & $33.95 \pm 3.06$ \\
\hline
\end{tabular}

\subsection{Chicken Production System}

The most dominant chicken production systems in the study area were the back yard or subsistence extensive systems $(72.3 \%)$ that are based on the local indigenous chickens and scavenging with occasional and seasonal supplementary feeding of homegrown grains and household food refusals (Table 2). About $84.2 \%$ of the replacement stock bought from the local market. The most important reasons for keeping chickens and producing eggs were primarily as source of income and for hatching, respectively. Men took the major ownership and decision on the chickens in the house. However, the major management activities pertinent to poultry production are the responsibility of women. There was separate simple overnight shelter made locally available material. The back yard chicken production system in the study area also characterized by high chick mortality caused by predators, and disease. The birds find their feed by scavenging among the houses in the village, and in addition, they might get leftovers from the harvest and from the kitchen with some supplements of homegrown grains. The free-range feeding practice in the study area also attributed to indiscriminate mating of cocks and hens. None of the farmers followed regular vaccination and de worming for their chicken. Very often birds do not get enough water, or they get dirty water, which may transfer diseases.

There were little effort made to distribute some exotic breeds as part of the extension package under went in the district, and extension support attached to management, veterinary and marketing extension services. Traditionally, households make use of their own local/indigenous poultry rearing knowledge acquired over a long period from their family.

Table2. Chicken production system in the study areas

\begin{tabular}{|l|l|l|}
\hline Production system & Frequency & Percent \\
\hline Traditional & 5 & 5.0 \\
\hline Scavenging with supplementation & 73 & 72.3 \\
\hline
\end{tabular}


Chicken Production and Marketing System under Farmer's Management Conditions in Arsi and Bale Zones, Oromia Region, Ethiopia

\begin{tabular}{|l|l|l|}
\hline Semi scavenging & 20 & 19.8 \\
\hline Intensive & 3 & 3.0 \\
\hline Total & 101 & 100.0 \\
\hline
\end{tabular}

\subsection{Flock Structure and Characteristics in the Study Areas}

Flock structure was described in terms of number of the different age group, sex in a flock and breeds. The mean values of chicken in different age and breed category and proportion of the respondents owning different size of chicken was indicated on (Table 3). The overall mean of flock size per household was 13.54 which was higher than 9.2 chickens per household reported by Mekonnen,(2007) and 8.8 chickens per household reported by Asefa (2007) in Ethiopia. Nevertheless, the value in this report was lower than Eugene et al. (2004) of Philippines, Sewannyana et al. (2004) of Uganda, and Khalafalla et al. (2000) of Sudan who reported the mean flock sizes of 19, 18 and 22, for village chicken production system, respectively. Flock size variation in rural areas has been attributing to the farming systems practiced and local factors such as diseases and predators (Kuitet al., 1986). In the highland area highest mean number of local hen 3.6 was observed followed by cross hen 2.8 and in midland highest mean of local hen 4.03 was observed followed by local chick 3.4 whereas in lowland highest mean of local chick 4.5 was observed followed by local hen 4.4 and cross hen 3.8.

Table3. Chicken flock structure in the study areas

\begin{tabular}{|l|l|l|l|l|}
\hline Parameter & $\begin{array}{l}\text { Highland } \\
\text { Mean } \pm \text { SE }\end{array}$ & $\begin{array}{l}\text { Midland } \\
\text { Mean } \pm \text { SE }\end{array}$ & $\begin{array}{l}\text { Lowland } \\
\text { Mean } \pm \text { SE }\end{array}$ & $\begin{array}{l}\text { Overall } \\
\text { Mean } \pm \text { SE }\end{array}$ \\
\hline Number of local hen & $3.58 \pm 0.35$ & $3.97 \pm 0.33$ & $4.41 \pm 0.69$ & $3.89 \pm 0.25$ \\
\hline Number of local cock & $1.35 \pm 0.15$ & $1.34 \pm 0.17$ & $2.71 \pm 0.52$ & $1.61 \pm 0.14$ \\
\hline Number of local pullet & $2.48 \pm 0.56$ & $2.27 \pm 0.55$ & $3.42 \pm 0.65$ & $2.58 \pm 0.34$ \\
\hline Number of local cockerels & $1.53 \pm 0.36$ & $1.20 \pm 0.47$ & $2.00 \pm 0.52$ & $1.53 \pm 0.25$ \\
\hline Number of local chicks & $2.77 \pm 0.72$ & $3.71 \pm 1.05$ & $4.50 \pm 1.31$ & $3.44 \pm 0.55$ \\
\hline Number of cross hen & $2.78 \pm 0.99$ & $1.82 \pm 1.17$ & $3.87 \pm 2.28$ & $2.61 \pm 0.73$ \\
\hline Number of cross cock & $.063 \pm 0.23$ & $0.86 \pm 0.42$ & $0.28 \pm 0.18$ & $0.65 \pm 0.19$ \\
\hline Number of cross pullet & $0.60 \pm 0.36$ & $0.21 \pm 0.21$ & $0.57 \pm 0.57$ & $0.44 \pm 0.20$ \\
\hline Number of cross cockerels & $0.40 \pm 0.23$ & & $0.42 \pm 0.42$ & $0.25 \pm 0.12$ \\
\hline Number of cross chicks & $0.73 \pm 0.73$ & $1.06 \pm 0.60$ & & $0.77 \pm 0.40$ \\
\hline Total number of flocks & $13.57 \pm 1.9$ & $13.21 \pm 2.05$ & $14.40 \pm 2.97$ & $13.54 \pm 1.24$ \\
\hline
\end{tabular}

\subsection{Purpose of Chicken Production in the Study Areas}

There were no taboos on production and consumption of both chickens and eggs in the study areas. They produce for home consumption, selling as income source and replacement stock. Thus, $20.8 \%$ and $21 \%$ of the respondents consume chickens and eggs per household per year respectively. The main objectives of chicken production were for sale (40.6\%) followed by replacement and consumption which accounted for 37.6\% and $20.8 \%$, respectively (Table 4). This indicated that the extensive backyard poultry production in the study area is mainly used to generate cash. Eggs are often used for incubation (45.5\%) aiming at replacing the off take and loss of chicken from the flock. This finding is close to Alemu, (2003) and Tadelle et al (2003) in the study of village chicken production system in Ethiopia who reported that about 50\% and $51.8 \%$ of the eggs produced are incubated in order to replace the new stock, respectively.

Table4. Purpose of chicken and egg production

\begin{tabular}{|l|l|l|}
\hline Purpose of chicken and egg production & & percent \\
\hline \multirow{3}{*}{ Egg production } & Hatching & 45 \\
\cline { 2 - 3 } & Selling & 34 \\
\cline { 2 - 3 } & Home consumption & 21 \\
\hline \multirow{3}{*}{ Chick production } & & 100 \\
\cline { 2 - 3 } & & \\
\cline { 2 - 3 } & Home Consumption & 21 \\
\cline { 2 - 3 } & Selling & 41 \\
\cline { 2 - 3 } & Replacement & 38 \\
\cline { 2 - 3 } & & 100 \\
\hline
\end{tabular}




\subsection{Reproduction and Productivity of Chicken}

Age of hen at first mating:-The present study indicated that the overall average age of hen at first mating and cock at first mating was 4.9 months. With no significant difference among the three agro ecologies, the overall average age at first egg was 5.4 months

Age at first egg laying: - Productivity of birds mainly depends on the production and management system followed in managing the chicken. Productivity of chicken can be compared in relation to the production system of the chickens. In the present study the overall age at first egg lying was 5.4 months .the result was similar with Barua and Yoshimura (2005) for Bangladesh reported the age at first egg laying was 5.75 months for the free-range and backyard chicken production systems. Egg production :based on the producer farmers response, the overall average numbers of clutches per year in this study was 3.2 (Table 5) Similar research from Uganda by Sewannyana et al (2004) reported average number of clutch per year was 3.1in village chicken production. The overall average length of inter clutch was 1.8 week. However the overall average egg production per hen per clutch was 15 , similar research by Mekonnen (2007) reported average egg production per hen per clutch was 14.9 which was relatively greater than the nation average eggs/hen/clutch 12 (CSA, 2003).The overall average length of single clutch and inter clutch was 2.9 and 1.9 week respectively.

The overall mean egg production per clutch was 15 eggs which is not similar with Fiker (2000) and Tadelle and Ogle (2001) reported 36-42 and 40-60 eggs in Ambo wereda and the central highlands of Ethiopia, respectively. Though the local birds in the area reached sexual maturity lately, they exhibited good egg production per clutch as well as per year with a relatively longer clutch size. The higher annual egg production in the study area could be attributed to the manipulation of hen laying cycle, i.e. discouraging brooding. Apart from this, there might be unknown genetic factors associated with the local breed. This could also be an indication of the potential for genetic improvement through selection. However, since egg production is affected by many factors, there is a need for further investigation. Age at first mating and egg lying, in different agro ecologies were described under (Table 5)

Table5. Reproductive performance of the hen based on hen history data obtained from the study village

\begin{tabular}{|l|l|l|l|l|}
\hline Parameter & $\begin{array}{l}\text { Highland } \\
\text { Mean } \pm \text { SE }\end{array}$ & $\begin{array}{l}\text { Midland } \\
\text { Mean } \pm \text { SE }\end{array}$ & $\begin{array}{l}\text { Lowland } \\
\text { Mean } \pm \text { SE }\end{array}$ & $\begin{array}{l}\text { Overall } \\
\text { Mean } \pm \text { SE }\end{array}$ \\
\hline Age of hen at first mating months & $4.79 \pm 0.29$ & $4.96 \pm 0.21$ & $5.10 \pm 0.21$ & $4.91 \pm 0.15$ \\
\hline Age of cock at first mating months & $4.81 \pm 0.31$ & $4.93 \pm 0.26$ & $5.10 \pm 0.28$ & $4.91 \pm 0.17$ \\
\hline Age at first laying months & $5.36 \pm 0.33$ & $5.37 \pm 0.25$ & $5.60 \pm 0.21$ & $5.41 \pm 0.17$ \\
\hline Average number of clutches per year & $3.37 \pm 0.45$ & $2.81 \pm 0.44$ & $2.61 \pm 0.38$ & $3.21 \pm 0.26$ \\
\hline average length of single seize (week) & $2.48 \pm 0.13$ & $2.63 \pm 0.14$ & $4.09 \pm 0.87$ & $2.89 \pm 0.21$ \\
\hline Average length of inter-clutch(wk) & $1.86 \pm 0.12$ & $1.69 \pm 0.11$ & $2.36 \pm 0.33$ & $1.92 \pm 0.10$ \\
\hline Average number of eggs per clutch & $15.36 \pm 0.72$ & $15.63 \pm 0.64$ & $13.38 \pm 0.81$ & $15.02 \pm 0.43$ \\
\hline
\end{tabular}

\subsection{Feed Source and Feeding of Chicken in the Study Areas}

Even though lack of feed supplementation is considered as one of the characteristics of a free-ranging backyard poultry production system, $97 \%$ of the respondents practiced supplementary feeding in this study result. Another study in AwassaZuria by Asefa (2007) also indicated that $95 \%$ of the households offer supplementary feed. According to the producer farmers' response, supplementary feed sources for scavenging chicken were harvest leftover, insects, grass and household leftover. This study result is similar with Tadelle et al. (2003) report that insects, grasses and harvest leftovers as source of scavenging for village chicken in Ethiopia. Thus, the smallholder chicken production goes eco-friendly because they convert insects and household leftover to valuable cheap and quality animal protein to the family.

The major feed and feeding practice of the three agro ecologies are summarized in (Table 6). The major supplementary feed in the surveyed area includes wheat (82\%), Household leftover (81\%) Maize (73\%), Barley (22\%), Wheat bran (9.9\%), Sorghum (7.9\%), in most cases, provision of feeds to chicken was seasonal. It also depends on the quantity and availability of the resources in there house. Based on the respondents response no/little supplementation is could be given by the end of dry season when the feed resource is becoming scarce. 
Chicken Production and Marketing System under Farmer's Management Conditions in Arsi and Bale Zones, Oromia Region, Ethiopia

Table6. Chicken supplementary feed types in the study areas

\begin{tabular}{|l|l|l|l|l|}
\hline Types of feed & Highland & Midland & Lowland & Overall \\
\cline { 2 - 5 } & Percent & Percent & Percent & Percent \\
\hline Wheat & 79 & 87 & 82 & 82 \\
Maize & 73 & 65 & 86 & 73 \\
Barley & 35 & 10 & 9 & 22 \\
Sourgum & 2 & - & 31 & 7.9 \\
Household leftover & 83 & 84 & 73 & 81 \\
Wheat bran & 6 & 12 & 13 & 9.9 \\
rice & - & - & - & - \\
Fingermillet & - & - & - & - \\
Sesame & - & - & - & - \\
Soyabean & - & - & - & - \\
Enset & 6 & - & - & 3 \\
Vegetable & - & 3 & - & 1 \\
\hline
\end{tabular}

\subsection{Housing of Chicken}

Housing is also essential to chickens as it protects them against predators, theft, rough weather (rain, sun, cold wind, dropping night temperatures) and to provide shelter for egg laying and broody hen. Therefore, the survey revealed that $44.6 \%$ of the respondents have separate house for their chicken. While $55.4 \%$ of respondents not have separate house for their chicken, due to the problem of predators, fear of theft and lack of knowledge and experience and lack of capital were the main reasons for not constructing separate poultry houses (table7). Concerning roosting arrangements, about $36.6 \%$ of the cases share the main house together with household to spend the night. In some cases $(10.9 \%)$, the chickens were allowed to perch in the kitchen. Housing facilities in the surveyed area were baskets and cartoons, within the keeper's dwelling and perches made of stick aiming at keeping the chickens at night. These baskets and cartoons were located on the floor or in the rafter space within the dwelling. This is obviously the most secure overnight location avoiding predators and theft but not safe for disease transitions.

Table7. Housingof scavenging chicken in the study areas

\begin{tabular}{|l|l|l|}
\hline Parameter & Frequency & Percent \\
\hline Separate shelter & 45 & 44.6 \\
\hline Perch in the house & 37 & 36.6 \\
\hline Perch in the chicken & 11 & 10.9 \\
\hline On the floor & 1 & 4.2 \\
\hline Veranda & 6 & 3.7 \\
\hline Total & 101 & 100 \\
\hline
\end{tabular}

\subsection{Predators and Diseases of Chicken in the Study Areas}

The major cause of illness and death of the chicken in the study area were seasonal occurrence of chicken disease, commonly Newcastle disease (local name fungle) followed by predation by wild cat. About $64.2 \%$ of chicken death was observed in during the rainy season (kremt) (June, July and August), $77 \%, 71 \%$ and $45.5 \%$ was observed in highland, midlandand lowland respectively. This finding is similar with Halima, 2007 research result in North western Ethiopia and Samson 2010 in mid rift valley of Oromia Region. It was indicated that in Africa including Ethiopia the major constraints of poultry production is the prevalence of various diseases (Gueye, 1998).Producers in the study area usually treat sick chicken using traditional medicine $(40.2 \%)$ otherwise do nothing $34.6 \%$. Only $15.2 \%$ of the respondents consult veterinarians during their chickens became sick; this is because of the lack of veterinary service nearby. Mostly farmers use pepper and oil to treat sick chicken and as prophylaxis of the healthy one. In addition to the above measures some of the respondents $34.5 \%$ isolate sick birds. Most of the respondents $48.1 \%$ throw away the dead birds in /close proximity to their yard which can be source of infection to the healthy chicken of themselves and neighbors. The response to treatment vary considerably $4 \%$ recovered, $32.7 \%$ partially recovery and $17.8 \%$ no response to traditional treatment. 


\subsection{Broody Hen Management}

In the traditional backyard poultry production system, by its very nature hens are responsible for the new flocks. Likewise in the study area, it is not uncommon to see hens with their follower chicks. Natural incubation is the most commonly used method for replacing and increasing the size of flocks. A broody hen often finds a dark and quite place in the house for laying eggs. After the eggs were collected, farmers adjust nest boxes for broody hens. Usually they use baskets, cartoons and they also sit the hen simply on the ground (putting some bedding materials like worn clothes, grass, straw) and in some cases use clay pot. Farmers are very conscious Very conscious and concerned in the preparation of appropriate nest boxes for incubation of broody hen. Assuming that there is good feed resources and Faber able environment for growing chicks during the dry seasons; about $90 \%$ of the respondents incubate and brood their hen during the dry seasons. About $10 \%$ of the respondents do not have any specific choice of season for incubation. Broodiness of a given chicken breed is genetically inherited. A bird has to be broody after laying eggs so that it would incubate, hatch the eggs and raise their young chicks. However, as opposed to commercial layer farms which select against broodiness, farmers (92\%) in the study area made selection towards broodiness based on different criteria including healthy broody hen(31\%),long and wide wing(28\%), mothering ability $(17 \%)$, breed(16\%), hatching ability(15\%), plumage color(3\%). On the average, 12.6 eggs were set per hen per clutch with an average hatchability of $88 \%$. The number of eggs set for natural incubation in this study was greater than reported by Asefa (2007) who reported 9.8 eggs. Nevertheless, the average number of eggs set in this study was all most similar to Alemu et al. (2003) report for other parts of Ethiopia.

Local hens are good sitters and show a good mothering ability, one of the desirable traits identified by the farmers. The ability to hatch their own eggs together with high hatchability makes the local chickens appropriate for the prevailing farming system. Nevertheless, it does not mean that there is no need for improvement.

In most of the cases, farmers let young chicks to follow their mother hen immediately after hatching. Consequently, chicks were subject to scavenge backyard with vigorous members of the flock, which is difficult to compete. Thus, this will result in poor nutrition, vulnerability to predation and disease, which ultimately causes high chick mortality during the first two months of age.

Traditionally all households attempt to increase egg production by stimulating broody birds to resume lying. Farmers in the study area practiced different methods to break broodiness in hens. these includes piercing the nostrils with a feather to prevent sitting (4\%), physically moving the bird to nearby house for a couple of days (27\%), by hanging the bird upside down for about 3-4 consecutive days (37\%) and disturbing the sitting nest-boxes (32\%). The purpose of such practices was to disturb the broody bird and to cause a hormonal shift so that it starts to lay eggs again within 8-10 days. Such practice could be responsible for the relatively better performance of the local chickens in the study area.

About $88.1 \%$ of the respondent had the experience in culling birds from the flock for different reasons. About $69 \%$ of the respondents avoid male birds from the flock to avoid cockfight and to maintain the existing male to female ratio. About $59 \%$ and $29.7 \%$ of the respondents remove hens from the flock due to low in productivity and anticipated occurrence of disease outbreak respectively. The remaining $11.3 \%$ of the respondents remove hens from the flock due to unwanted plumage color. This result indicates that farmers in the study area remove chickens of both sex for different reasons and purpose.

\subsection{Chicken Marketing practice}

The major characteristics of chicken markets are shown in (Table 8). In general, there is no systematic marketing operation of poultry and poultry products in the study areas. Selling of live birds and eggs were a common practice in the country as well as in the study sites. About 84.6 percent of live chickens was sold at the local market (73), neighbors (4.2), both local market and neighbor (16.2) and nearby market (9.4). Women's (57.7) were the major responsible in selling birds and egg followed by men youth(16.6) On the average, farmers in the surveyed area traveled $5.1 \mathrm{~km}$ ranged from 3-6 $\mathrm{Km}$ to reach to the main markets (secondary markets). The modes of transportation of chickens for producer (farmers) were mainly by hand usually embracing (77.2) and vehicle (8.1) and animal court (6.9). 
Chicken Production and Marketing System under Farmer's Management Conditions in Arsi and Bale Zones, Oromia Region, Ethiopia

Table8. Chicken marketing practice in the study areas

\begin{tabular}{|c|c|c|c|c|}
\hline Variables & Highland $(\mathrm{N}=48)$ & Midland(N=31) & Lowland(N=22) & Overall \\
\hline \multicolumn{5}{|l|}{ Sell chicken $(\mathrm{HH})$} \\
\hline Yes & 87.5 & 93.5 & 72.7 & 84.6 \\
\hline No & 12.5 & 6.5 & 27.3 & 15.4 \\
\hline \multicolumn{5}{|l|}{ Place of selling chicken } \\
\hline Local market & 72.9 & 64.3 & 81.8 & 73 \\
\hline Neighbors & 4.2 & 0 & 0 & 4.2 \\
\hline Nearby market & 12.5 & 6.7 & 9.1 & 9.4 \\
\hline local market and neighbors & 10.4 & 29 & 9.1 & 16.2 \\
\hline \multicolumn{5}{|l|}{ quality specification } \\
\hline Yes & 91.6 & 90.3 & 81.8 & 87.9 \\
\hline No & 8.4 & 9.7 & 18.2 & 12.1 \\
\hline \multicolumn{5}{|l|}{ Demand of chicken and egg } \\
\hline Very high & 18.7 & 19.4 & 36.4 & 24.8 \\
\hline High & 56.3 & 35.4 & 54.5 & 48.7 \\
\hline Low & 6.25 & 9.7 & 9.1 & 8.4 \\
\hline Very low & 4.2 & 0 & 0 & 4.2 \\
\hline Medium & 14.6 & 12.9 & 0 & 9.2 \\
\hline \multicolumn{5}{|l|}{ Who sell chicken } \\
\hline Women & 47.9 & 70.9 & 54.5 & 57.7 \\
\hline Men & 10.4 & 9.6 & 2.3 & 7.4 \\
\hline Men youth & 20.8 & 6.5 & 22.7 & 16.6 \\
\hline Women and men & 4.2 & 6.5 & 4.5 & 5.1 \\
\hline Women and men youth & 10.4 & 0 & 13.5 & 7.9 \\
\hline No response & 6.5 & 3.2 & 2.5 & 4.1 \\
\hline \multicolumn{5}{|l|}{ Chicken price fluctuation } \\
\hline Yes & 79.2 & 87 & 90.1 & 85.4 \\
\hline No & 28.8 & 13 & 9.9 & 14.6 \\
\hline \multicolumn{5}{|l|}{ Means of transport } \\
\hline Caring & 87.5 & 80.6 & 63.7 & 77.2 \\
\hline Vehicle & 4.2 & 6.4 & 13.6 & 8.1 \\
\hline Animal cart & 2.1 & 9.6 & 9.1 & 6.9 \\
\hline No response & 6.2 & 0 & 13.6 & 6.6 \\
\hline \multicolumn{5}{|l|}{ Do you sell egg } \\
\hline No & 22.9 & 9.6 & 0 & 10.8 \\
\hline Yes & 77.1 & 90.4 & 100 & 89.2 \\
\hline \multicolumn{5}{|l|}{ Where to sell eggs } \\
\hline Market & 64.5 & 67.7 & 59.1 & 63.76 \\
\hline Village & 22.9 & 19.4 & 31.8 & 24.7 \\
\hline Home & 12.5 & 12.9 & 9.1 & 11.5 \\
\hline
\end{tabular}

Price of chicken and chickenproducts:-The respondent estimation of chicken price during holidays and during different season is presented in (Table 9). Variations in poultry prices are not only influenced by weight and age of chickens but also by seasons and holidays. Farmers get better prices for both egg and live birds during holiday markets. According to farmers, comparatively higher prices birr 94, 106 and 110 per birds were given for large cock in highland, mid land and lowland respectively and birr60, 73 and 70 per birds were given for large hen in highland, midland and lowland respectively during Christian holidays. The same is true during Muslim holidays and dry season. However the prices lower during wet season in all agro ecologies. The prices offered in this findings were relatively higher compared to (Tadelle et al., 2003) who reported birr 21.5 with a range of 12.5-30 birr and birr 13.4 with a range of 9-10 birr for matured cock and matured female, respectively during holidays. This finding is still higher than that of Asefa (2007) who reported birr 27.24, 15.51 for matured male and female birds, respectively the study conducted in and around UmbulloWachuwatershed of AwassaZuria in Ethiopia. 
Chicken Production and Marketing System under Farmer's Management Conditions in Arsi and Bale Zones, Oromia Region, Ethiopia

Table9. Chicken price in Ethiopian birr in the study area during the study period

\begin{tabular}{|c|c|c|c|c|c|c|c|c|c|c|c|c|}
\hline \multirow{4}{*}{$\begin{array}{l}\text { Chicken } \\
\text { category }\end{array}$} & \multicolumn{4}{|c|}{ Highland(Mean SE) } & \multicolumn{4}{|c|}{ Midland(SEM) } & \multicolumn{4}{|c|}{ Lowland(SEM) } \\
\hline & \multicolumn{2}{|c|}{ Holiday } & \multirow[t]{3}{*}{ sumer } & \multirow[t]{3}{*}{ Winter } & \multicolumn{2}{|l|}{ Holiday } & \multirow[t]{3}{*}{ Sumer } & \multirow[t]{3}{*}{ winter } & \multirow{2}{*}{\multicolumn{2}{|c|}{ Holiday }} & \multirow[t]{3}{*}{ summer } & \multirow[t]{3}{*}{ winter } \\
\hline & \multirow{2}{*}{\multicolumn{2}{|c|}{ Christian|Muslim }} & & & \multirow{2}{*}{\multicolumn{2}{|c|}{ ChristianMuslim }} & & & & & & \\
\hline & & & & & & & & & \multicolumn{2}{|c|}{ Christian|Muslim } & & \\
\hline $\begin{array}{l}\text { Small } \\
\text { male }\end{array}$ & $54 \pm 3$ & $40 \pm 4$ & $51 \pm 3$ & $36 \pm 2$ & $64.5 \pm 4$ & $38 \pm 7$ & $47 \pm 6$ & $32 \pm 4$ & $63 \pm 4$ & $47 \pm 5$ & $51 \pm 5$ & $35 \pm 4$ \\
\hline $\begin{array}{l}\text { Medium } \\
\text { male }\end{array}$ & $72 \pm 3$ & $54 \pm 5$ & $64 \pm 4$ & $47 \pm 3$ & $87 \pm 5$ & $53 \pm 9$ & $56 \pm 7$ & $41 \pm 5$ & $80 \pm 4$ & $63 \pm 5.4$ & $65 \pm 5$ & $49 \pm 4$ \\
\hline $\begin{array}{l}\text { Large } \\
\text { male }\end{array}$ & $95 \pm 5$ & $71 \pm 7$ & $84 \pm 5$ & $59 \pm 4$ & $107 \pm 6$ & $68 \pm 12$ & $66 \pm 9$ & $51 . \pm 6$ & $111 \pm 4$ & $85.3 \pm 6.8$ & $85 \pm 7$ & $58.6 \pm 6$ \\
\hline $\begin{array}{l}\text { Small } \\
\text { female }\end{array}$ & $37 \pm 2$ & $29 \pm 3$ & $34 \pm 2$ & $24 \pm 2$ & $45 \pm 3$ & $28 \pm 5$ & $32 \pm 5$ & $20 \pm 3$ & $43 \pm 3$ & $33 \pm 3$ & $37 \pm 4$ & $26 \pm 3$ \\
\hline $\begin{array}{l}\text { Medium } \\
\text { female }\end{array}$ & $48 \pm 3$ & $36 \pm 4$ & $44 \pm 2$ & $33 \pm 2$ & $61 \pm 4$ & $35 \pm 6$ & $38 \pm 5$ & $27 \pm 3$ & $57 \pm 5$ & $48 \pm 7$ & $50 \pm 7$ & $33 \pm 3$ \\
\hline $\begin{array}{l}\text { Large } \\
\text { female }\end{array}$ & $61 \pm 3$ & $44 \pm 5$ & $54 \pm 4$ & $39 \pm 3$ & $74 \pm 4$ & $45 \pm 8$ & $47 \pm 6$ & $36 \pm 4$ & $71 \pm 6$ & $59 \pm 8$ & $58 \pm 8$ & $41 \pm 4$ \\
\hline Unit egg & $2 \pm 0.1$ & $1.3 \pm 1$ & $2 \pm 0.5$ & $1.3 \pm 0.2$ & $1.3 \pm 0$ & $0.8 \pm 0$ & $2 \pm 0.1$ & $1.3 \pm 0.1$ & $1.8 \pm 0.1$ & $2.0 \pm 0.8$ & $1.8 \pm 0.1$ & $2 \pm 0$ \\
\hline
\end{tabular}

Plumage color of chicken in the study areas: - different color preferences of chickens were recorded (Table 10). It was found that red color preference covered about $74 \%$ and $85 \%$ for hen and cock respectively. The next most commonly colors were white followed by, grey (Gebsema), golden, black and mixed color (composed of white with black spot, red with black spot). The high percent of red colored chicken preference was related to the high market demand.

Table10. Plumage color preference in the study areas

\begin{tabular}{|l|l|l|}
\hline \multirow{2}{*}{ Plumage color } & Hen & Cock \\
\cline { 2 - 3 } & Rank & Rank \\
\hline Red & $74 \%\left(1^{\text {st }}\right)$ & $85 \%\left(1^{\text {st }}\right)$ \\
\hline White & $53 \%\left(2^{\text {nd }}\right)$ & $54 \%\left(2^{\text {nd }}\right)$ \\
\hline Grey & $38 \%\left(3^{\text {rd }}\right)$ & $29 \%\left(3^{\text {rd }}\right)$ \\
\hline Black & $13 \%\left(4^{\text {th }}\right)$ & $6 \%\left(4^{\text {th }}\right)$ \\
\hline Golden & $10 \%\left(5^{\text {th }}\right)$ & $5 \%\left(5^{\text {th }}\right)$ \\
\hline Mixed color & $4 \%\left(6^{\text {th }}\right)$ & $2 \%\left(6^{\text {th }}\right)$ \\
\hline
\end{tabular}

\subsection{Major Constraints of Poultry Production in the Study Areas}

The major constraints of poultry production in the study area in different agro-ecology were ranked in (table 11). The first problem in lowland and midland production system were poultry disease, whereas price fluctuation was the first challenge to poultry production at the Highlands of Arsi and Bale Zones of Oromia region, Ethiopia. Lack of improved breeds is ranked first in the low land areas of the study areas.

Table11. Major constraints of poultry production in different agro ecologies

\begin{tabular}{|l|l|l|l|}
\hline chicken productionconstraints & Highland & Midland & Lowland \\
\hline Disease outbreak & $10\left(2^{\text {nd }}\right)$ & $5\left(1^{\text {st }}\right)$ & $4\left(1^{\text {st }}\right)$ \\
\hline Feed shortage & 0 & 0 & $2\left(2^{\text {nd }}\right)$ \\
\hline Low production & 0 & 0 & $1\left(3^{\text {rd }}\right)$ \\
\hline Lack of vet service & $1\left(6^{\text {th }}\right)$ & $1\left(3^{\text {rd }}\right)$ & $1\left(3^{\text {rd }}\right)$ \\
\hline Seasonal variation & $3\left(5^{\text {th }}\right)$ & $2\left(2^{\text {nd }}\right)$ & 0 \\
\hline Christian/Muslim cultural festival & $1\left(7^{\text {th }}\right)$ & $\left.13^{\text {rd }}\right)$ & 0 \\
\hline Fasting period & $2\left(6^{\text {th }}\right)$ & $1\left(3^{\text {rd }}\right)$ & $1\left(3^{\text {rd }}\right)$ \\
\hline Predator attack & $5\left(3^{\text {rd }}\right)$ & $2\left(2^{\text {nd }}\right)$ & 0 \\
\hline Price variation & $17(1 \mathrm{st})$ & $5\left(1^{\text {st }}\right)$ & $2\left(2^{\text {nd }}\right)$ \\
\hline Supply shortage & $1\left(6^{\text {th }}\right)$ & $1\left(3^{\text {rd }}\right)$ & $2\left(2^{\text {nd }}\right)$ \\
\hline Lack of improved breed & $4\left(4^{\text {th }}\right)$ & 0 & $5\left(1^{\text {st }}\right)$ \\
\hline
\end{tabular}

\section{CONCLUSION}

Poultry production in Ethiopia is a chain of interrelated economic activities undertaken within a social context. These activities can range from the raising of poultry to the buying and selling of poultry and 
poultry products. Understanding the scenario of poultry production, market and marketing chain, and the dynamics within the system is crucial to develop strategies and improve the system. A vast number of household women and children actively participate in poultry production using their own indigenous breed and local knowledge of poultry management to generate income and/or to complement the protein requirement of the households. The most dominant chicken production systems in the study area were the back yard extensive systems based on the local indigenous chicken and scavenging with supplementary feeding of homegrown grains and household food refusals with some specific poultry houses. The reported critical constraints of the smallholder poultry production in the study area were partly due to the prevailing poor management practices, in particular predation, lack of proper health care, poor housing and poor marketing information. None of the respondents has access to proper vaccination program and proper prevention mechanism to their chickens. As it is the case for most rural areas in Ethiopia, there were also no well-organized formal poultry and poultry products marketing systems which need attention on value chain approach to improve marketing for better poultry production productivity.

\section{REFERENCES}

[1] Central Statistical Authority.2017. Statistical Report on Livestock and Livestock Characteristics (PrivatePeasant Holdings). Statistical Bulletin 587, Volume II, April 2018. Addis Ababa

[2] Halima H. 2007. Phenotypic and Genetic Characterization of Indigenous Chicken Populations in Northwest Ethiopia.PhD dissertation, Department of Animal, Wildlife and Grassland Sciences University of the Free State, Bloemfontein, South Africa.

[3] Cumming R B .1992. Village chicken production: problems and potential. Spradbrow, p. b. (editor) proceedings of an international workshop on Newcastle disease in village chickens, control with thermo stable oral vaccines 6-10 October, 1991, Kuala Lumpur, Malaysia, pp 21-24.

[4] Tadelle D and Ogle B. 2001. Village Poultry Production Systems in the Central Highlands of Ethiopia.TropicalAnimal Health and Production. 33(6): 521-537.

[5] Alemu Y .2003.Village chicken production systems in Ethiopia: use patterns and performance valuation and chicken products and socio-economic functions of chicken livestock research for rural deveilopment 15 (1) 2003. http://www.cipav.org.co/irrd/irrd15/1/

[6] Gausi J C K, Safalaoh A C L, Banda J W and Ng'ong'ola D H .2004 .Characterization of the smallholder poultry marketing systems in rural Malawi: A case study of Malingunde Extension Planning Area.LivestockResearchforRuralDevelopment16 (12) 2004. http://www.lrrd.org/lrrd16/12/gaus16097.htm

[7] Dwinger R H, Bell J G and Permin A. 2003. A program to improve family poultry production in Africa. B.P. 6268, Rabat-Institutes, Morocco

[8] Alemu Y and Tadelle D. 1997. The status of poultry research and development in Ethiopia.Research Bulletin No.4.Poultry Commodity Research Program DebreZeit Agricultural Research Center, Alemaya University ofAgriculture, Ethiopia.pp. 62.

[9] Abera M.2000 .Comparative studies on performance and physiological responses Ethiopia indigenous (AngeteMelata) chickens and their fcrosses to long term heat exposure. PhD dissertation, Martin-Luther University. Halle-Wittenberg Germany. pp127.

[10] Solomon D. 2004. Egg production performance of local and white leghorn hens under intensive and rural household conditions in Ethiopia.Jimma College of agriculturep.obox.307, Jimma, Ethiopia

[11] Ethio-Italian Development Project .2002.Atlas of Arsi Zone.Arsi Agricultural and Rural Development Bureau, Assela,Ethiopia.

[12] The National Regional Government of Oromia, Bureau of finance and Economic DevelopmentRegional Statistic .2012. http://www.oromiabofed.org/

[13] Gebremariam H.1992.Availa bility and Use of Seed in Ethiopia. Program Support Unit,Canadian International Development Agency (CIDA), Addis Ababa

[14] Williams S .2002. Bale Mountains: a guidebook. United Printers, Addis Ababa, Ethiopia.p 52

[15] SARC .2001.Profile of Sinana Agricultural Research Center (SARC) .Oromia Agricultural Research Institute. Working Document Series 1, November 2001, Addis Ababa, Ethiopia.

[16] Central Statistical Authority .2003. Statistical report on livestock and farm implements, part iv, Addis Ababa, Ethiopia 82

[17] Mekonen G. 2007. Characterization of the Small Holder Poultry Production and Marketing System of Dale, Wonsho and LokaabayaWeredas of Southern Ethiopia. M.Sc. Thesis Presented to School of Graduate Studies ofHwassa University, Ethiopia. 
[18] Asefa T .2007 .Poultry management practices and on farm performance evaluation of Rhode Island Red (RIR), Fayoumi and local chicken in UmbulloWachu watershed.M.Sc. Thesis. Department of animal and range sciences, Hawassa College of agriculture, Awassa, Ethiopia.

[19] Eugene F .2004. A longitudinal analysis of chicken production systems of smallholder farmers in Leyte, Philippines. Leyte State University, Leyte, the Philippines.

[20] Sewannyana ES,sali A,Kasadha T, Dhikusooka MKasoma and Kalema P.2004. Characterization of indigenous chickens of Uganda, Kampala, Uganda. Statistical Package for Social Sciences. 1996. SPSS for windows. User's guide: Statistics version 13. Inc. Cary, NC.

[21] Khalafalla SW H. 2000. Village poultry production in Sudan. Department of micro biology, Faculty of veterinary science, University of Khartoum, Khartoum, North Sudan.

[22] Kuit H G, Traore A \& Wilson R T . 1986. Livestock production in central Mali:Ownership, management and productivity of poultry in traditional sector. Tropical Animal Health and Production.18: 222-231.

[23] Tadelle D, Million T, Alemu Y, and Peter K J. 2003. Village chicken production system in Ethiopia. Use patterns and performance evaluation and chicken products and socio-economic function of chicken. Humboldt University of Berlin, animal breeding for tropics and sub tropics.Philoppstr.13, Hause 9, 10115, Berlin.

[24] Barua A and Yoshimura Y. 2005 .Rural poultry keeping in Bangladish. World's poultry science Journal.53:387-394.

[25] Fikre A.2000.Base line data on chicken population, productivity, husbandry, feeding and constraints in four peasant associations in Ambo Wereda. Department of Animal Sciences, Ambo College of Agriculture, Ambo, Ethiopia.

[26] Samson L and Endalew B. 2010. Survey on Village Based Chicken Production and Utilization System in Mid Rift Valley of Oromia, Ethiopia. Global Veterinaria 5 (4): 198-203.

[27] Gueye, E HF. 1998. Village egg and fowl meat production in Africa.World's Poult. Sci. J. 54: 73-86.

Citation: MulualemAmbaw, et.al. "Chicken Production and Marketing System under Farmer's Management Conditions in Arsi and Bale Zones, Oromia Region, Ethiopia” International Journal of Research Studies in Agricultural Sciences (IJRSAS), 2020; 6(1), pp. 18-28, http://dx.doi.org/10.20431/2454-6224.0601003

Copyright: () 2020 Authors. This is an open-access article distributed under the terms of the Creative Commons Attribution License, which permits unrestricted use, distribution, and reproduction in any medium, provided the original author and source are credited. 